\title{
COMPARATIVE PERFORMANCE OF THE INDIGENOUS AND EXOTIC SOWS IN NIGERIA
}

\section{MILK YIELD, PERSISTENCY OF PRODUCTION UTILIZATION BY THE LITTER}

AND

\section{By}

\author{
Adebambo Olufunmilayo* A. and Almut. E. Dettmers \\ Department of Animal Science \\ University of Ibadan, Ibadan, Nigeria.
}

\section{SUMMARY}

THE indigenous sow of Nigeria which is about half the size of the exotic large white, Landrace or crossbred pigs at maturity (60 vs $128-141 \mathrm{~kg}$ ) has an average milk yield of $75 \mathrm{~kg}$ as compared to 130 $148 \mathrm{~kg}$ of the exotic breeds during an eight week lactation. Peak production was reached between the third and fifth weeks of lactation by the imported, while the native sow showed quite a slight peak but with greater persistency. For all genotypes compared, milk yield was lower in the dry season $(P<0.05)$ than in the wet season $(123$ vs $134 \mathrm{~kg})$ and higher for sows $(\mathrm{P}<0.05)$ than for gilts (135 vs $121 \mathrm{~kg}$ ).

With an average litter size of $5-8$ pigs, available milk per piglet was between $16 \mathrm{~kg}$ in the Indigenous sow and $28 \mathrm{~kg}$ in the Landrace sows $(P<0.05)$ and a significant difference $(P<0.05)$ in efficiency of milk utilization by the piglets in the range of Crossbred, followed by the purebreds, the indigenous being the least efficient in relation to unit metabolic size Milk production did not differ among the genotypes.

The high positive correlations $(\mathrm{P}<0.05)$ between milk yield and body weight at farrow and the unit metablic size as well as between milk intake and litter size might serve as a useful tool in selection for the Nigerian Indigenous pigs as the higher body weight tend to be correlated to a higher milk yield and a correspondingly large litter size.

\section{INTRODUCTION}

IN Nigeria with a population of about 70 million there are fewer than one million pigs, the majority of which is indigenous. Thus on the average 1.2 pigs are raised per hundred people or, if moslem who do not eat pork are excluded, about two to three pigs are available for 100 persons. Pork production should be encouraged as one of the means to increase the amount of badly needed protein from animal sources in the diet of the average Nigerian.

The indigenous pigs are found in the south of the country and mostly along the coast of West Africa. These small-bodied pigs producing few litters roam about as scavengers in compounds and villages. They are considered of poor performance, inefficient and uneconomical to be used for commercial production (Fetuga, Babatunde and Oyenuga, 1976). They have however not been thoroughly studied and assessed since interest in them has arisen only very recently.

Milk yield of sow vary with differences in breed, management, litter size and vigour of piglets (Bonsma and Oosthuizen 1935, Berber, Braude, and Mitchell 1935 and Allen, Lasley and Tribble 1959). Information on milk yield of sows is available only for standard breeds of pigs in the temperate zones. This paper therefore provides some information on milk yield of such breeds in the tropical environment along with that of indigenous sows.

\section{MATERIALS AND METHODS}

The research was conducted on the University of Ibadan farm. Ibadan has a wet season with two peaks of rainfall in June and October and a dry season lasting five months from November through March. Average precipitation during the

*Present Address: Institute of Agric, Research \& Training.

P.M.B. 5029, Moor Plantation, Ibadan, Nigeria. 
last five years was $1230 \mathrm{~mm}$, average humidity $73 \%$ and minimum and maximum temperatures were 22 and $31^{\circ} \mathrm{C}$ during this period.

\section{Animals :}

A total of 113 female pigs were used consisting of Landrace (LR), Large white (LW) and Indigenous (IND) purebreds and cross-breds among the exotics large white and landrace reciprocal matings (LW.LR or LR.LW) or matings with Duroc boars (D.LW or L.LR) and using the $F_{1} S$ in the Diallel cross.

The foundation stock of the exotics was imported as far back as 1952 from Great Britain and Sweden and are therefore considered adapted to the tropical environment. The indigenous pigs were obtained from different sources in the vicinity of Ibadan. Their body colours vary from solid black to almost white with different black-white colour combination in between.

Feed:

All pigs were kept in the same barn on concrete floor. The dams farrowed in stalls which have small attached concrete runs for feeding and exercise of the sow and separate pens for piglets where creep feed could be provided. Feed samples containing the following components were analysed weekly. The average composition was $87.7 \%$ dry matter, $16.3 \%$ protein, $4.2 \%$ ether extract on dry matter basis for the sow feed while the corresponding figures for the creep feed were 90.3, 17.6 and $3.6 \%$. Water was available at all times.

\section{Procedure:}

Gilts or sows were moved to their farrowing quarters about one week before parturition to be flushed before farrowing. They were weighed after parturition, so were the piglets which were ear notched at the same time. From a previous study by Adebambo and Dettmers where suckling frequency and nursing behaviour had been established and the suckling intervals determined, the milk intake was measured by the indirect weighing method following this procedure. Average litter size was computed as the means of number of pigs alive after the first week and the number of pigs at eight weeks of age, while efficiency of milk utilization was calculated on the amount of milk ingested per $\mathrm{kg}$ live weight gained by the litter.

\section{Statistical analysis:}

The statistical model used for the analysis of variance was the Hierarchal classification (Singh and Chaudhary 1977). Differences between means within genotypes were tested by Duncan's (1955) multiple range procedure.

\section{RESULTS}

The mean milk yields per lactation and the variation for the seven genotypes of sows are shown in Table 1. The Duroc sired crossess produced the largest amount of milk, closely followed by the reciprocal crosses in which the large white was the female, while the exotic pure breds did not differ much, the large white was the higher producer. The Indigenous sows produced less $(\mathrm{P}<0.01)$ than the imported purebreds and crossbreds by almost half. The milk yield was singificantly higher during the second than the first lactation (135 vs $120.9 \mathrm{~kg}$ ) for all sows and gilts combined.

\section{Lactation Trend:}

The lactation trend for the different sows is shown in Table 2 and Figure 1 in which weekly yields are given for each genotype. With the exception of the Landrace and Landrace large-white sows, the exotic breeds reached their highest production in the third week of their lactation and the former one week later, after which a sharp decline occurred. The indigenous pigs showed a much more gradual decline in milk yield, even though their piglets were offered creep feed just the same. It is noteworthy that, even though her weekly milk yield was lower than that of the exotic dams, there was little varia- 


\section{THE INDIGENOUS AND EXOTIC SOWS IN NIGERIA}

TABLE 1

Average Milk Yield per Lactation (kg) for seven Genotypes of Sows

\begin{tabular}{|c|c|c|c|c|c|c|}
\hline Genotype & & & $N$ & Mean & S.D. & CV \% \\
\hline $\begin{array}{l}\text { IND } \\
\text { LW } \\
\text { LR } \\
\text { D.LW } \\
\text { D.LR } \\
\text { LW.LR } \\
\text { LR.LW }\end{array}$ & $\begin{array}{l}\cdots \\
\cdots \\
\cdots \\
\cdots \\
\cdots \\
\cdots\end{array}$ & $\begin{array}{l}\ldots \\
\cdots \\
\cdots \\
\cdots \\
\cdots \\
\cdots\end{array}$ & $\begin{array}{l}18 \\
21 \\
20 \\
16 \\
14 \\
12 \\
12\end{array}$ & $\begin{array}{c}73,99 a \\
137.68 \\
133.35 \\
148.32 \\
153.21 \\
129.18 \\
144.67\end{array}$ & $\begin{array}{l}17.51 \\
42.20 \\
44.18 \\
34.02 \\
39.65 \\
33.31 \\
39.36\end{array}$ & $\begin{array}{l}23.67 \\
30.65 \\
33.13 \\
22.94 \\
35.88 \\
25.79 \\
27.21\end{array}$ \\
\hline
\end{tabular}

$a=$ Mean differs from the others

$* *=\mathrm{P}<0.01$

TABLE 2

Analysis of variance (mean squares) for milk yield, milk/piglet, efficiency of milk utilization and milk per metabolic body size

\begin{tabular}{lcccccc}
\hline Source of variation & d.f. & Milk yield & Milk/piglet & $\begin{array}{c}\text { Efficiency of } \\
\text { utilization }\end{array}$ & Milk/W 0.73 \\
\hline Season (s) & $(2-1)$ & 1 & $3277.92^{*}$ & 14.71 & 0.07 & $1.81^{*}$ \\
Bred w/s (b) & $2(7-1)$ & 12 & $9212.76^{* *}$ & $156.36^{*}$ & $16.37^{*}$ & 0.39 \\
Age w/b (a) & $7(3-1)$ & 14 & $3250.72^{*}$ & 69.04 & 5.1 & $2.60^{*}$ \\
Error within & 85 & 1228.17 & 50.09 & 5.23 & 0.90 \\
\hline
\end{tabular}

* $=\mathrm{P}<0.05$ and $* *=\mathrm{P}<0.01$

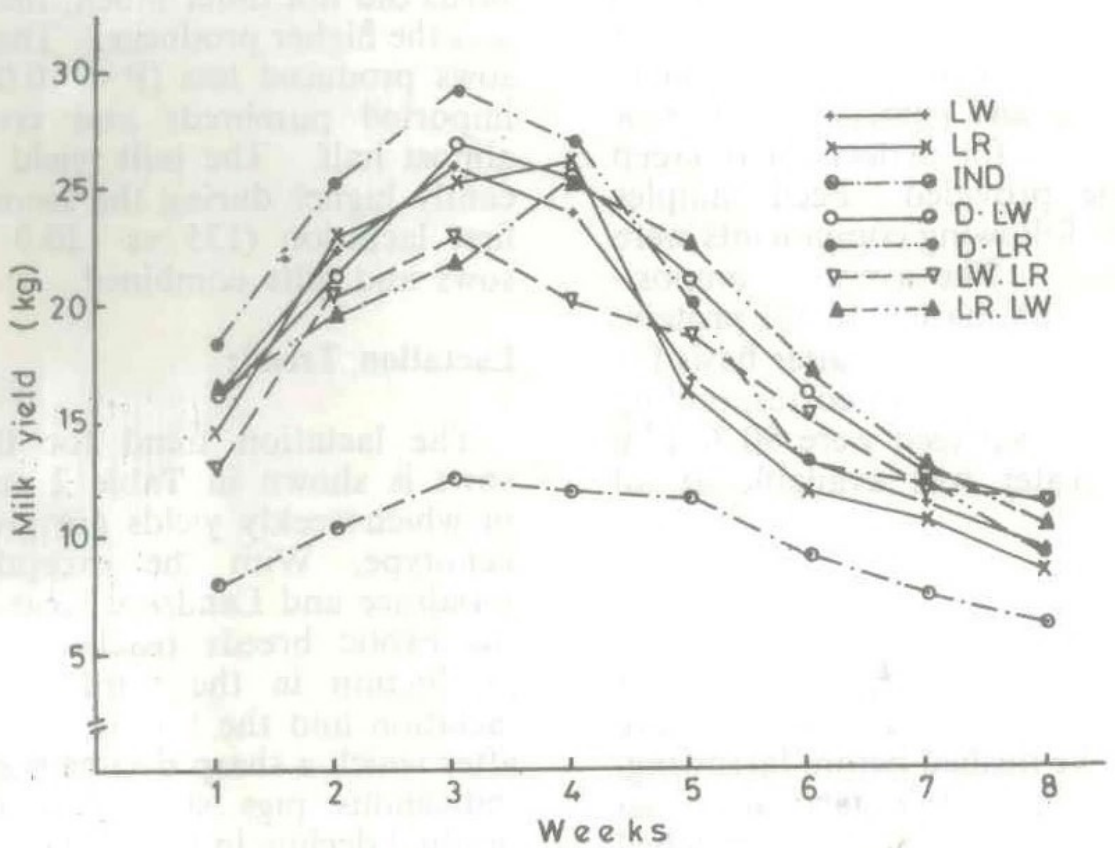

Fig 1. Weokly Milk yield per lactation. 


\section{ADEBAMBO and DETTMERS}

tion from week to week and towards the end of the nursing period it was still nearly as high as that of the temperate breeds.

\section{Milk Production per Piglet:}

Total milk produced divided by the average litter size was taken as amount of milk produced per piglet (Table 3). Amount of milk per piglet differed $(\mathrm{P}<0.05)$ among breeds, milk production of the indigenous sow per piglet was lower than that of the temperate breeds, but significantly so only compared to the Landrace and Largewhite - Landrace cross.

\section{Efficiency of Milk Utilization:}

The most efficient utilizers of milk for growth were the offspring of crossbred dams in which the Landrace was the female (LW.LR and D.LR). They required the least milk (2.92 and $2.97 \mathrm{~kg}$ ) per kilogram gain of the litter. They were followed by progeny of the crossbred dams with large white females (LR.LW and D.LW). The purebred sows were considerably less efficient, significantly less was the indigenous sows (Table 4) though there was slight improvement in milk utilization of litter from sows compared to gilts ( 3.95 vs $4.46 \mathrm{~kg}$ ).

TABLE 3

Weekly and total milk yields (kg) and litter size by genotype of sows

\begin{tabular}{cccccccc}
\hline Week & IND & $L \dot{W}$ & $L R$ & $D . L W$ & $D . L R$ & $L W . L R$ & $L R . L W$ \\
\hline 1 & 7.87 & 15.64 & 14.21 & 15.79 & 18.17 & 12.26 & 16.18 \\
2 & 10.38 & 22.27 & 22.75 & 21.07 & 25.07 & 19.53 & 19.44 \\
3 & 12.30 & 25.79 & 25.06 & 26.91 & 29.07 & 22.54 & 21.66 \\
4 & 11.61 & 23.89 & 25.96 & 25.28 & 26.66 & 19.82 & 25.14 \\
5 & 11.48 & 16.64 & 16.26 & 20.87 & 19.80 & 18.15 & 22.43 \\
6 & 8.82 & 13.03 & 11.44 & 15.79 & 13.08 & 14.93 & 16.58 \\
7 & 7.09 & 11.08 & 10.44 & 12.55 & 12.25 & 11.39 & 12.84 \\
8 & 5.88 & 9.39 & 8.26 & 11.50 & 9.09 & 10.56 & 10.41 \\
\hline Mean & 73.99 & 137.68 & 133.35 & 148.32 & 153.21 & 129.18 & 144.64 \\
yield & \pm 0.46 & \pm 9.21 & \pm 9.89 & \pm 8.51 & \pm 10.61 & \pm 9.63 & \pm 11.38 \\
$\mathrm{~N}$ & 18 & 21 & 20 & 16 & 14 & 12 & 12 \\
Litter & 4.83 & 6.93 & 5.08 & 7.97 & 7.68 & 6.96 & 7.04 \\
size & \pm 0.46 & \pm 0.42 & \pm 0.40 & \pm 0.42 & \pm 0.39 & \pm 0.86 & \pm 0.90 \\
\hline
\end{tabular}

TABLB 4

Average quantity of milk produced per piglet $(\mathrm{kg})$

\begin{tabular}{lccccc}
\hline Genotypes & $N$ & Litter size & Milk/piglet & $S . D$ & $C V \%$ \\
\hline IND & 18 & $4.83 \pm 0.43$ & $16.01 \mathrm{ac}$ & 4.34 & 27.11 \\
LW & 21 & $6.93 \pm 0.41$ & 20.14 & 4.39 & 21.80 \\
LR & 20 & $5.08 \pm 0.42$ & $27.71 \mathrm{ab}$ & 7.28 & 26.27 \\
D.LW & 16 & $7.97 \pm 0.42$ & $18.75 \mathrm{~b}$ & 2.98 & 15.89 \\
D.LR & 14 & $7.68 \pm 0.39$ & 20.34 & 5.05 & 24.83 \\
LW.LR & 12 & $6.96 \pm 0.86$ & $24.85 \mathrm{c}$ & 13.91 & 55.88 \\
LR.LW & 12 & $7.04 \pm 0.90$ & 24.35 & 10.49 & 43.10 \\
\hline
\end{tabular}

$a-c=$ Means with same superscript differ from each other.

${ }^{*}=\mathrm{P}^{0} 0.05$ 


\section{THE INDIGENOUS AND EXOTIC SOWS IN NIGERIA}

\section{Seasonal Variation:}

The analysis of variance (Table 5) showed that there was a seasonal effect. Mílk yield was $122.8 \mathrm{~kg}$ for all breeds during the dry season and $133.6 \mathrm{~kg}$ during the wet season. Between breeds the Large white produced more during the dry season than the Landrace surpassing all other exotic by about $20 \mathrm{~kg}$ difference.

\section{Milk Production in relation to body size:}

Calculating the ratio of milk produced per unit metablic body size (Table 6) it, became obvious that the very low milk yield of the indigenous sow has un- doubtedly something to do with the body size. Average milk production per metabolic body size did not differ by genotype, the indigenous pig included. there was however a difference due to parity $(\mathrm{P}<0.05)$ with values of 3.75 for gilts as against 4.02 for sows.

\section{Phenotypic Relationships:}

There was a high and significant positive correlation between milk yield and unit metabolic body size and also with body weight at farrow ranging from 0.56 to 0.76 in the first instance and from 0.53 to 0.75 in the second (Table 7). The indigenous sows showed the strongest

TABLE 5

Milk intake (kg) per unit weight gained by the litter

\begin{tabular}{lcccc}
\hline Genotypes & $N$ & Milk intake & $S . D$. & $C V \%$ \\
\hline IND & 18 & $5.93 \mathrm{abc}$ & 3.38 & 57.00 \\
LW & 21 & 4.79 & 1.26 & 26.30 \\
LR & 20 & 4.66 & 1.74 & 37.34 \\
D.LW & 16 & 3.52 & 1.30 & 36.93 \\
D.LR & 14 & $2.97 \mathrm{a}$ & 0.53 & 17.85 \\
LW.LR & 12 & $1.92 \mathrm{~b}$ & 0.67 & 22.95 \\
LR.LW & 12 & $3.14 \mathrm{c}$ & 0.93 & 29.62 \\
\hline
\end{tabular}

a-c $=$ Means with same superscript differ from each other.

${ }^{*} \equiv \mathrm{P} \bigodot_{0} 0.05$

TABLE 6

Milk produced per unit metabolic body size (kg) by seven genotypes of pigs

\begin{tabular}{lccccccc}
\hline & IND & $L W$ & $L R$ & D.LW & D.LR & LW.LR & LR.LW \\
\hline GILTS & 3.63 & 4.35 & 3.98 & 3.63 & 3.68 & 3.08 & 3.44 \\
SOWS & 4.75 & 3.23 & 3.38 & 4.75 & 4.80 & 4.02 & 4.55 \\
ALL & 4.26 & 3.71 & 3.68 & 4.26 & 4.24 & 3.63 & 3.99 \\
\hline
\end{tabular}

TABLE 7

Phenotypic relationships between milk produced, metabolic body size and body weight at farrow (kg)

\begin{tabular}{|c|c|c|c|c|c|c|}
\hline Genotype & $r$ & $\begin{array}{l}\text { Metabolic body size } \\
\text { Regression Equation }\end{array}$ & $p$ & $r$ & $\begin{array}{c}\text { Body Weight } \\
\text { Regression Equation }\end{array}$ & $p$ \\
\hline IND & 0.786 & $Y-26.67 \pm 2.274 X$ & ** & 0.745 & $Y-36.73 \pm 0.574 X$ & *** \\
\hline LW & 0.699 & $\mathbf{Y}-22.99 \pm 3.099 \mathrm{X}$ & ** & 0.681 & $\mathrm{Y}-31.17 \pm 0.767 \mathrm{X}$ & ** \\
\hline LR & 0.560 & $Y-32.28+2.717 X$ & $*$ & 0.532 & $Y-48.88 \pm 0.601 X$ & $*$ \\
\hline D.LW & 0.750 & $Y-24.54+4.245 X$ & ** & 0.714 & $Y-38.47 \pm 0.813 X$ & *** \\
\hline D.LR & 0.690 & $Y-32.41+3.130 X$ & $* *$ & 0.639 & $\mathrm{Y}-50.41 \pm 0.696 \mathrm{X}$ & * \\
\hline LW.LR & 0.696 & $Y-33.96 \pm 2.457 X$ & $*$ & 0.631 & $\mathrm{Y}-45.87 \pm 0.573 \mathrm{X}$ & $*$ \\
\hline LR.LW & 0.700 & $Y-30.04 \pm 3.095 X$ & $*$ & 0.664 & $Y-46.12 \pm 0.704 X$ & ** \\
\hline
\end{tabular}

* $=\mathrm{P}<0.05$

$* *=\mathrm{P}<0.01$ 


\section{ADEBAMBO and DETTMERS}

association. The regression coefficients ranged from 2.3 to $4.2 \mathrm{~kg}$ increase in milk for one kilogram metabolic body size and from 0.6 to $0.8 \mathrm{~kg}$ body weight at farrow.

\section{Lactational Weight Loss:}

All the sows lost weight during the eight week lactation period (Table 8). Average weight at farrow ranged from 128 to $141 \mathrm{~kg}$ in the exotic breeds while the indigenous weighed less than half of that. Weight losses during lactation ranged between 22 and $34 \mathrm{~kg}$ for all of them. While these losses were between 22 and $26 \%$ of the body weight in the exotic sows the indigenous dams lost $36 \%$ of her weight during lactation.
$\mathrm{LR}>\mathrm{LW}$.LR> LR.LW> D.LR> $>$ LW $>$ D.LW with milk intakes of $27.7,24.9,24.4,20.3,20.1$ and $18.8 \mathrm{~kg} / \mathrm{pig}$ and corresponding litter sizes of $5.1,6.5,7.0,7.7,6.9$ and 8.0 pigs. The exception was the indigenous sow with both fewer pigs in the litter and a lower intake of milk.

The observation in the temperate breeds agree with reports by other workers (Schneider 1934; Bonsma and Oosthuizen 1935; Lalevic 1953) who gave average litters of $6,7-9$ and 10 or more pigs.

Though the milk yield and average litter size was less for pigs in this study, efficiency of milk utilization was in agreement with reports by others.

\section{TABLE 8}

Weight at farrow (kg) and weight lost during lactation (\%)

\begin{tabular}{lrrrrrrr}
\hline & $I N D$ & $L W$ & $L R$ & D.LW & D.LR & LW.LR & LR.LW \\
\hline Weight at & & & & & & & \\
farrow & 60.46 & 140.96 & 137.61 & 128.34 & 138.44 & 133.33 & 138.26 \\
Weight lost & 22.04 & 28.15 & 33.12 & 33.09 & 34.30 & 28.77 & 26.31 \\
\% Loss & 36.45 & 19.97 & 24.06 & 25.75 & 24.78 & 21.58 & 19.03 \\
\hline
\end{tabular}

\section{DISCUSSION}

Total yields of milk for the temperate breeds of pigs in this study were very much lower than reported in the literature per yields in the temperate climate. Olofson and Larson (1930) and Berber et al (1955) obtained 230.6 and $348.4 \mathrm{~kg}$ for the Yorkshire breed and $318.2 \mathrm{~kg}$ for the Landrace sow. The lower yields reported here were suspected to be due to the tropical environment. The sharp decline in milk production from the third week was also reported by Allen et al (1959). At this time during the nursing period, the piglets eat creep feed and are not solely dependent on their dams milk supply, litter size is a major variable and indicator of milk production of the sow. When the intake of milk by the litter was considered, pigs from breeds with smaller litters took more milk than those with larger litters. Genotypes of sows ranged in the order, of
Legagneur and Fevrier (1960) estimated that $4 \mathrm{~kg}$ of milk would be required to produce $1 \mathrm{~kg}$ of live weight of nursing pigs.

\section{CONCLUSION}

The indigenous sow of Nigeria compares well with sows of the larger imported breeds of swine and crosses among these breeds with regard to milk yield in relation to body size which in turn is related to the small litter size. Fetuga et al (1976) found that under intensive management with adequate rations, native pigs farrowed larger litters comparable to exotic stock and they had fewer losses up to weaning. The strong correlation between milk yield and body size reported here suggests that selection for larger body size could have a correlated response for higher milk yield and thus enable the sow to nurse a larger litter. 


\section{THE INDIGENOUS AND EXOTIC SOWS IN NIGERIA}

Furthermore, according to the same authors, maximum growth of indigenous pigs was obtained between 45 and $57 \mathrm{~kg}$ live weight beyond which gain became uneconomical and that these pigs required less total feed. It was also reported that indigenous pigs can be maintained on a lower dietary level (Ilori 1974). These findings suggest lower cost of feed. In addition, the larger degree of persistency of milk production of the indigenous sow reported in this study indicates that they could be raised without or with little of the expensive creep feed, that is with considerably lower cost. On the other hand, a commercial producer may be able to increase preweaning gain by providing creep feed and practising selections for larger body size at the same time.

Raising indigenous pigs in Nigeria thus becomes feasible and much more worthwhile than previously thought of. The indigenous pig could contribute efficiently to pig and pork production in the country because of its proportionately lower cost to the farm producers.

\section{REFERENCES}

Allen, A. D., Lasley, J. F. and L. F. Tribble.
1959. Milk Production and related performance factors in sows. University of Missouri. Agri. Exp. Sta. Nes. Bull. 712.

Berber, R. S, Braude, R. and K. G. Mitchell. 1955. Studies on milk production of Large White pigs. J. Agr. Sci. 46, 97-118.

Bonsma, F. M. and P. M. Oosthuizen. 1935 Milk production in Large Black Sows. S. Afr. J. Sci. 32, 360-378.

Ducan, D. B. 1955. Multiple range and multiple F-test. Biom. 11: 1-42.

Fetuga, B. L. Babatunde, G. M. and V. A. OYENUGA. 1976. Performance of the indigenous pigs of Nigeria under intensive management conditions. Niger. J. Anim. Prod. 3, 148-161.

ILORI, J. O. 1974. Assessing the prodictive potentials of local breeds of pigs. 1 Effect

of protein levels on performance. Niger. $J$. Anim. Prod. 1, 100 (Abstract).

LALEviC, D. 1953. Milk production of Marava pigs. Anim. Breed Abstracts 22: 241.

LEGAGNEUR, S. and R. FEVRIER. 1960. The nursing of baby pigs. Rs. Med. Vet. 136, 945-956.

Olofson, M. E. and S. Larson. 1930. Milk production in sows and development of suckling pigs. Med. Centr. Anstr. Forsoksv., Stockholm.

SCHENIDER, K. T. 1934. The milk production of German high quality pigs and the weight development of the piglets during the eight week suckling period. Land. Jahrb. 3, 80 .

Singh B. K. and B. D. Chaudhury 1977. Biometrical methods in quantitative genetic analysis Kalyani Publishers. New Delhi Ludhiana. 